Sławomir Kasperczyk $k^{1}$

http://dx.doi.org/10.13075/mp.5893/2013/0013

Michał Dobrakowski ${ }^{1}$

Alina Ostałowska ${ }^{1}$

Aleksandra Kasperczyk ${ }^{1}$

Sławomir Wilczyński

Magdalena Wyparło-Wszelaki ${ }^{3}$

Jacek Kiełtucki ${ }^{4}$

Ewa Birkner ${ }^{1}$

\title{
LEAD-ELEVATED ACTIVITY OF XANTHINE OXIDASE IN LEAD-EXPOSED WORKERS
}

\author{
INDUKCJA AKTYWNOŚCI OKSYDAZY KSANTYNOWEJ PRZEZ OŁÓW \\ U ZAWODOWO NARAŻONYCH PRACOWNIKÓW
}

\begin{abstract}
${ }^{1}$ Medical University of Silesia in Katowice / Śląski Uniwersytet Medyczny w Katowicach, Zabrze, Poland Department of Biochemistry, School of Medicine with the Division of Dentistry / Zakład Biochemii Ogólnej, Katedra Biochemii, Wydział Lekarski z Oddziałem Lekarsko-Dentystycznym

${ }^{2}$ Medical University of Silesia in Katowice / Śląski Uniwersytet Medyczny w Katowicach, Sosnowiec, Poland Department of Biophysics, School of Pharmacy with the Division of Laboratory Medicine / Katedra i Zakład Biofizyki, Wydział Farmaceutyczny z Oddziałem Medycyny Laboratoryjnej

${ }^{3}$ Eko-Prof-Med Medical Centre / Centrum Medyczne Eko-Prof-Med, Miasteczko Śląskie, Poland

${ }^{4}$ Independent Public Health Care Centre in Staszów / Samodzielny Publiczny Zespół Zakładów Opieki Zdrowotnej w Staszowie, Staszów, Poland

Department of Internal Medicine / Oddział Chorób Wewnętrznych
\end{abstract}

\begin{abstract}
Background: The aim of the present study was to explore the connection between lead toxicity and the activity of xanthine oxidase (XO). In addition, we indicated the uric acid (UA) and creatinine levels and concentration of erythrocyte malondialdehyde (MDA) to estimate oxidative stress intensity. Materials and Methods: The examined group consisted of 125 healthy male employees of zinc and lead works. The examined group was divided into tertiles according to blood lead levels. In the collected blood samples, concentrations of lead-exposure indices, UA, creatinine, and MDA as well as activity of XO were measured concomitantly. The control group consisted of 32 healthy male administrative workers who were exposed to lead only environmentally. Results: XO activity and MDA level were significantly elevated in all tertiles compared to the control group. Creatinine level was significantly elevated in the medium and high tertiles. However, the level of UA was significantly elevated in the high tertile, while in the low and medium tertile only a tendency toward higher values was observed. Conclusions: Occupational exposure to lead induces activity of XO. This induction may contribute to the observed simultaneously increased oxidative stress, measured as MDA level, and the increased level of UA. Med Pr 2013;64(2):175-180
\end{abstract}

Key words: lead poisoning, xanthine oxidase, uric acid, creatinine, oxidative stress

\section{STRESZCZENIE}

Wstęp: Celem pracy była analiza wpływu narażenia na ołów na aktywność oksydazy ksantynowej (xanthine oxidase - XO). Dodatkowo wyznaczono stężenia kwasu moczowego (uric acid - UA) i kreatyniny. Natężenie stresu oksydacyjnego oszacowano na podstawie stężenia dialdehydu malonowego (malondialdehyde - MDA). Materiał i metody: Grupę badaną stanowiło 125 zdrowych pracowników huty cynku i ołowiu. Stopień narażenia na ołów oceniano na podstawie stężenia ołowiu i cynkoprotoporfiryny we krwi, a także kwasu delta-aminolewulinowego w moczu. Na podstawie stężenia ołowiu we krwi grupa badana została podzielona na tercyle. W próbkach krwi uzyskanych od uczestników badania dokonano analizy wyżej wymienionych parametrów biochemicznych. Grupę kontrolną stanowiło 32 zdrowych pracowników administracji nienarażonych na ołów. Wyniki: Aktywność XO i stężenie MDA były znamiennie wyższe we wszystkich tercylach w porównaniu z grupą kontrolną. Stężenie kreatyniny osiągnęło także znamiennie wyższe wartości, lecz tylko w środkowym i górnym tercylu. Z kolei stężenie UA było znamiennie wyższe wyłącznie w górnym tercylu. Jednocześnie zaobserwowano tendencję do wyższych wartości jego stężenia w dwóch pozostałych tercylach.

Medical University of Silesia supported this work no. KNW-1-083/P/2/0, titled „Wpływ stresu oksydacyjnego wywołanego ołowiem na właściwości biofizyczne erytrocytów i osocza krwi u ludzi" ("The influence of lead-induced oxidative stress on biophysical properties of human erythrocytes and plasma"). Manager of the project: Ewa Birkner, professor. 
Wnioski: Zawodowe narażenie na ołów indukuje wzrost aktywności XO, który może przyczyniać się do nasilenia stresu oksydacyjnego, mierzonego jako stężenie MDA, i powodować wzrost stężenia UA. Med. Pr. 2013;64(2):175-180

Słowa kluczowe: zatrucie ołowiem, oksydaza ksantynowa, kwas moczowy, kreatynina, stres oksydacyjny

Corresponding author: Department of Biochemistry, Medical University of Silesia,

Jordana 19, 41-808 Zabrze, e-mail: kaslav@mp.pl

Received: 2013, February 7, accepted: 2013, April 5

\section{INTRODUCTION}

Lead is a pleiotropic toxicant. Health effects at high blood lead levels are demonstrable, while the effects at lower blood levels of lead remain unclear (1). Despite the fact that there is no safe level of exposure to lead, it has been widely used in industry due to its malleability, resistance to corrosion, and low melting point. Lead accumulates in bones, liver, kidneys, and other organs one hour after intestinal absorption. Exposure to lead results in many adverse health effects, including behavioral disorders or the dysfunction of liver, kidneys and many systems of the human body, such as the hematological, the immunological, and the nervous system (2).

The mechanisms involved in lead toxicity are poorly understood, nevertheless, it is well-documented that one of the most important toxic effects of lead is oxidative stress. Lead generates reactive oxygen species (ROS), such as superoxide radicals, hydrogen peroxide, or hydroxyl radicals, and weakens antioxidant defenses. Lead does not only deplete glutathione (GSH) content but also alters the expression and activities of antioxidant enzymes, such as superoxide dismutase (SOD) or glutathione peroxidase (GPx). In consequence, elevated levels of lipid peroxidation products, including malondialdehyde (MDA), have been reported in lead poisoning (3).

Lead influences activities of enzymes via interactions with sulfhydryl groups and metal cofactors. An inhibitory effect of lead on delta-aminolevulinic acid dehydratase (ALAD) and ferrochelatase is well-known. As a result, lead impairs the chain reaction that leads to the formation of heme and causes anemia. Due to the fact that the accumulation of delta-aminolevulinic acid (ALA) and zinc protoporphyrin (ZPP) occurs simultaneously, levels of these compounds are used as human lead-exposure indices (4).

Lead-exposure has been associated also with increased serum uric acid (UA) level. However, this association remains unclear, especially among individuals without chronic kidney disease. Hyperuricemia associated with lead poisoning may be due to the increased production or decreased excretion of UA. The decreased excretion of UA may occur in lead-induced nephropathy and be a result of the isolated proximal tubular defects $(1,5)$. On the other hand, the production of UA depends on the activity of xanthine oxidase (XO) (6). Ariza et al. (7) demonstrated that lead ions elevate XO activity in AS52 cells. Xanthine oxidase does not only catalyse the formation of UA but also generates ROS. Therefore, the elevated activity of XO could hypothetically explain the association between lead poisoning and both the increased ROS production and hyperuricemia. To our knowledge, in the available literature, there is no study on this topic conducted on humans. In the light of this, the aim of the present study was to explore the connection between lead toxicity and the activity of XO. In addition, we indicated the UA and creatinine levels and the concentration of erythrocyte MDA to estimate oxidative stress intensity.

\section{MATERIALS AND METHODS}

\section{Study population}

The examined group consisted of 125 male employees of zinc and lead works localized in Miasteczko Śląskie. Their age ranged between 23 and 59 years. They were exposed to lead from 1 to 38 years. Workers suffering from chronic diseases and receiving any drugs were excluded.

Blood lead levels $(\mathrm{PbB})$ and concentrations of $\mathrm{ZPP}$ in the blood and ALA in the urine served as the biomarkers of lead-exposure. All of these indices had been determined, on average, every three months during two years of observation and afterwards mean values of them were calculated $\left(\mathrm{PbB}_{\text {mean }}, \mathrm{ZPP}_{\text {mean }}, \mathrm{ALA}_{\text {mean }}\right)$. The examined group was divided into tertiles according to the $\mathrm{PbB}_{\text {mean }}$ levels (low tertile $-\mathrm{PbB}_{\text {mean }}=20.0-31.6 \mu \mathrm{g} / \mathrm{dl}$, medium tertile $-\mathrm{PbB}_{\text {mean }}=31.7-40.0 \mu \mathrm{g} / \mathrm{dl}$, high tertile $\left.\mathrm{PbB}_{\text {mean }}=40.1-56.2 \mu \mathrm{g} / \mathrm{dl}\right)$. 
In the last collected blood samples, concentrations of $\mathrm{PbB}, \mathrm{ZPP}, \mathrm{UA}$, and creatinine as well as activity of $\mathrm{XO}$ were measured concomitantly. To obtain erythrocytes for MDA concentration, ethylenediaminetetraacetic disodium acid solution as anticoagulant was used. ALA levels were determined in the urine samples.

Control group consisted of 32 healthy male administrative workers who were exposed to lead only environmentally and had no history of occupational exposure to lead. Their age ranged between 28 and 57 years. Every individual in this group had the levels of $\mathrm{PbB}$ or ZPP lower than the normal levels which were $10 \mu \mathrm{g} / \mathrm{dl}$ and $2.5 \mu \mathrm{g} / \mathrm{g} \mathrm{Hb}$, respectively.

\section{Laboratory procedures}

Whole blood was used for the analysis of $\mathrm{PbB}$ and $\mathrm{ZPP}$. The concentration of $\mathrm{PbB}$ was measured by graphite furnace atomic absorption spectrophotometry. Unicam 929 and 939OZ Atomic Absorption Spectrometers with GF90 and GF90Z Graphite Furnaces were used. Data was shown in $\mu \mathrm{g} / \mathrm{dl}$. The concentration of ZPP was measured directly using the Aviv Biomedical hematofluorometer model 206. The instrument measured the ratio of fluorescent substance (ZPP) to the absorption of light in the sample (hemoglobin). Results were displayed as $\mu \mathrm{g}$ ZPP per gram of hemoglobin $(\mu \mathrm{g} / \mathrm{g} \mathrm{Hb})$.

The concentration of ALA was measured in the urine samples by Grabecki et al. (8). In this method, ALA reacted with acetylacetone and formed a pyrrole substance which reacted with dimethylaminobenzoese aldehyde. The colored complex was measured spectrophotometrically. Results were expressed as $\mathrm{mg} / \mathrm{dl}$.

The activity of XO was measured in serum according to Majkić-Singh et al. (9). In this method, chromogen 2,2'-azino-di(3-ethylbenzthiazoline-6-sulfonate) (ABTS) was oxidized in the system of coupled reactions catalyzed by $\mathrm{XO}$, uricase, and peroxidase. The absorbance of oxidized ABTS was directly proportional to the XO activity. Results were expressed as U/l.

The concentration of UA was measured using the A25 biochemical analyzer (BioSystems, Spain) according to the manufacturer's instructions. Results were expressed as $\mu \mathrm{mol} / \mathrm{l}$.

The concentration of MDA in hemolysate of erythrocytes was determined by assaying the thiobarbituric acid reactive substance (TBARS) according to the method of Ohkawa et al. (10) using spectrofluorometer LS45 (Perkin Elmer). To improve the specificity of the method, we used sodium sulfate and butylated hy- droxytoluene (BHT). Results were expressed as $\mu$ moles per dl of erythrocytes ( $\mu \mathrm{mol} / \mathrm{dl}$ of erythrocytes).

The concentration of creatinine was measured by the method with picric acid. Results were expressed as $\mathrm{mg} / \mathrm{dl}$.

\section{Statistical analysis}

Statistica 9.1 PL software was used to perform the statistical analysis. Statistical methods included the mean and standard deviation. Levene's test was used to verify the homogeneity of variances. Shapiro-Wilk test was used to verify normality. Statistical comparisons between the examined groups and the control group were made by a $\mathrm{t}$-test, $\mathrm{t}$-test with a separate variance estimates, or a Mann-Whitney U test. The Spearman non-parametric correlation was also calculated. The value of $\mathrm{p}<0.05$ was considered to be significant.

\section{RESULTS}

There were no significant differences in the mean age, body mass index (BMI), and smoking habits between the examined population and the control group.

The biomarkers of lead-exposure were significantly higher in the exposed group compared to the controls.

Xanthine oxidase activity was significantly elevated in all tertiles compared to the control group. The level of UA was significantly elevated in the high tertile, while in the low and the medium tertile only a tendency toward higher values was observed. The concentration of creatinine was significantly elevated in the medium and high tertiles, while erythrocyte MDA level was significantly elevated in all tertiles compared to the control group (Table 1).

The Spearman correlation showed that there are positive correlations between lead-exposure markers and MDA level. Besides, XO activity correlates positively with $\mathrm{PbB}, \mathrm{ALA}$, and MDA levels (Table 2).

\section{DISCUSSION}

Purine oxidation is catalyzed by xanthine oxidoreductase (XOR) that catabolizes hypoxanthine to xanthine and then to UA by hydroxylation (11). Xanthine oxidoreductase is a molybdenum iron-sulfur flavin hydroxylase and it is present in various organs, such as the liver, gut, lungs, kidneys, heart, brain, and plasma. Xanthine oxidoreductase exists in two inter-convertible forms: XO (EC 1.1.3.22) and xanthine dehydrogenase $(\mathrm{XDH})(\mathrm{EC}$ 1.17.1.4) (12). The xanthine dehydrogenase form of the enzyme uses $\mathrm{NAD}^{+}$as the preferred electron 
Table 1. The epidemiologic parameters, the levels of lead in the blood ( $\mathrm{PbB})$, the levels of zinc protoporphyrin in blood ( $\mathrm{ZPP}$ ), the levels of delta-aminolevulinic acid in the urine (ALA), the activity of xanthine oxidase (XO), and the levels of uric acid (UA), creatinine, and malondialdehyde (MDA) in the study population

Tabela 1. Dane epidemiologiczne, stężenie ołowiu $(\mathrm{PbB})$ we krwi, stężenie cynkoprotoporfiryny (ZPP) we krwi, stężenie kwasu delta-aminolewulinowego (ALA) w moczu, aktywność oksydazy ksantynowej (XO) oraz stężenie kwasu moczowego (UA), kreatyniny i dialdehydu malonowego (MDA) w badanej populacji

\begin{tabular}{|c|c|c|c|c|c|c|c|c|c|c|c|c|}
\hline \multirow{3}{*}{$\begin{array}{l}\text { Parameter } \\
\text { Parametr }\end{array}$} & \multirow{2}{*}{\multicolumn{2}{|c|}{$\begin{array}{l}\text { Control group } \\
\text { Grupa kontrolna } \\
\quad(\mathrm{N}=32)\end{array}$}} & \multicolumn{9}{|c|}{$\begin{array}{l}\text { Study population } \\
\text { Badani }\end{array}$} & \multirow{3}{*}{$\frac{\text { ANOVA }}{\mathrm{p}}$} \\
\hline & & & \multicolumn{3}{|c|}{$\begin{array}{l}\text { low tertile } \\
\text { dolny tercyl } \\
(\mathrm{N}=42)\end{array}$} & \multicolumn{3}{|c|}{$\begin{array}{l}\text { medium tertile } \\
\text { środkowy tercyl } \\
\quad(\mathrm{N}=41)\end{array}$} & \multicolumn{3}{|c|}{$\begin{array}{l}\text { high tertile } \\
\text { górny tercyl } \\
(\mathrm{N}=42)\end{array}$} & \\
\hline & M & $\mathrm{SD}$ & M & SD & $\mathrm{p}$ & M & $\mathrm{SD}$ & $\mathrm{p}$ & $\mathrm{M}$ & $\mathrm{SD}$ & $\mathrm{p}$ & \\
\hline $\begin{array}{l}\text { Seniority [years] / Staż pracy } \\
\text { [w latach] }\end{array}$ & - & - & 18.20 & 11.50 & - & 17.80 & 10.00 & - & 17.60 & 10.30 & - & 0.860 \\
\hline Weight / Masa ciała $[\mathrm{kg}]$ & 80.90 & 9.94 & 80.20 & 12.20 & 0.795 & 81.60 & 12.90 & 0.806 & 81.20 & 12.20 & 0.900 & 0.960 \\
\hline BMI & 26.60 & 2.74 & 26.30 & 3.38 & 0.660 & 26.80 & 3.15 & 0.837 & 27.30 & 4.20 & 0.444 & 0.625 \\
\hline Smokers / Palący [\%] & 50.00 & - & 55.00 & - & 0.689 & 46.00 & - & 0.760 & 52.00 & - & 0.842 & 0.890 \\
\hline $\mathrm{ZPP}_{\text {mean }} / \mathrm{ZPP}_{\text {sr. }}[\mu \mathrm{g} / \mathrm{g} \mathrm{Hb}]$ & 1.91 & 0.69 & 3.87 & 3.03 & 0.001 & 4.81 & 2.55 & $<0.001$ & 6.36 & 3.77 & $<0.001$ & $<0.001$ \\
\hline $\mathrm{ZPP}[\mu \mathrm{g} / \mathrm{g} \mathrm{Hb}]$ & 1.93 & 0.72 & 4.28 & 2.90 & $<0.001$ & 5.41 & 3.26 & $<0.001$ & 7.87 & 5.33 & $<0.001$ & $<0.001$ \\
\hline $\mathrm{ALA}_{\text {mean }} / \mathrm{ALA}_{\text {sr. }}[\mathrm{mg} / \mathrm{l}]$ & 2.28 & 0.85 & 3.45 & 1.03 & $<0.001$ & 3.80 & 0.92 & $<0.001$ & 4.21 & 1.13 & $<0.001$ & $<0.001$ \\
\hline ALA $[\mathrm{mg} / \mathrm{l}]$ & 2.18 & 0.84 & 3.10 & 1.07 & $<0.001$ & 3.00 & 1.31 & 0.003 & 3.55 & 1.51 & $<0.001$ & $<0.001$ \\
\hline $\mathrm{UA}[\mu \mathrm{mol} / \mathrm{l}]$ & 4.52 & 0.80 & 4.87 & 0.97 & 0.104 & 4.94 & 1.25 & 0.107 & 5.25 & 1.36 & 0.008 & 0.050 \\
\hline $\mathrm{XO}$ activity $[\mathrm{U} / \mathrm{l}]$ & 0.54 & 0.21 & 0.93 & 0.43 & $<0.001$ & 1.03 & 0.70 & $<0.001$ & 0.86 & 0.37 & $<0.001$ & $<0.001$ \\
\hline Creatinine / Kreatynina [mg/dl] & 0.95 & 0.14 & 1.00 & 0.10 & 0.060 & 1.03 & 0.13 & 0.012 & 1.010 & 0.14 & 0.050 & 0.048 \\
\hline $\begin{array}{l}\text { MDA [ } \mu \mathrm{mol} / \mathrm{dl} \text { erythrocytes/ } \\
\text { / erytrocytów] }\end{array}$ & 15.80 & 4.04 & 19.60 & 3.84 & $<0.001$ & 20.10 & 3.91 & $<0.001$ & 20.90 & 2.90 & $<0.001$ & 0.005 \\
\hline
\end{tabular}

Low tertile / dolny tercyl: $\mathrm{PbB}=20.0-31.6 \mu \mathrm{g} / \mathrm{dl}$; medium tertile / środkowy tercyl: $\mathrm{PbB}=31.7-40.0 \mu \mathrm{g} / \mathrm{dl}$; high tertile / górny tercyl: $\mathrm{PbB}=40.1-56.2 \mu \mathrm{g} / \mathrm{dl}$. BMI - body mass index / wskaźnik masy ciała.

$\mathrm{M}$ - mean / średnia.

$\mathrm{SD}$ - standard deviation / odchylenie standardowe.

acceptor, while the $\mathrm{XO}$ form uses oxygen as the electron acceptor, producing superoxide anions and hydrogen peroxide. Xanthine oxidoreductase originally exists in the $\mathrm{XDH}$ form, but could be converted to $\mathrm{XO}$ either reversibly by oxidation of cysteine residues to form disulfide bridges or irreversibly by proteolysis $(6,12,13)$.

The results of the present study support the findings of Ariza et al. (7). Consistently, Kilikdar et al. (14) reported the increased activity of XO in rats administered with lead acetate in the dose of $15 \mathrm{mg} / \mathrm{kg}$ body weight. However, Prasanthi et al. (15) observed the decreased activity of XO in the brains of developing and adult mice exposed to lead. According to the authors of this study, the decrease of XO activity may be due to the binding of lead to the sulfhydryl groups of the enzyme. On the other hand, the interactions between lead and the sulfhydryl groups under other conditions may contribute to the increased conversion of XDH to XO. Besides, lead could theoretically induce structural changes in the enzyme by replacing essential metals (7). The hypothetic ability of lead to induce the conversion of XDH to XO supports our results and may also explain why exposure to lead induces oxidative stress and elevates the UA level. Due to the fact that lead-exposure alters the levels of IL-1 and TNF- $\alpha$ (4), which have been shown to upregulate the transcription of XOR (12), the second possible explanation for our results may be associated with lead-induced changes in the immunological response. 
Table 2. Correlations (Spearman $\mathrm{R}$ values) between the analyzed parameters

Tabela 2. Korelacje Spearmana

\begin{tabular}{|c|c|c|c|c|}
\hline \multirow{2}{*}{$\begin{array}{l}\text { Parameter } \\
\text { Parametr }\end{array}$} & \multicolumn{4}{|c|}{$\begin{array}{c}\text { Correlations (Spearman R values) } \\
\text { Współczynnik R korelacji }\end{array}$} \\
\hline & $\begin{array}{l}\text { creatinine } \\
\text { kreatynina }\end{array}$ & UA & $\mathrm{XO}$ & MDA \\
\hline $\mathrm{PbB}_{\text {mean }} / \mathrm{PbB}_{\text {śr. }}$ & 0.16 & 0.18 & 0.29 & 0.31 \\
\hline $\mathrm{PbB}$ & 0.17 & 0.20 & 0.26 & 0.30 \\
\hline $\mathrm{ZPP}_{\text {mean }} / \mathrm{ZPP}_{\text {sr. }}$ & ns & 0.19 & 0.16 & 0.23 \\
\hline ZPP & ns & 0.17 & 0.17 & 0.31 \\
\hline $\mathrm{ALA}_{\text {mean }} / \mathrm{ALA}_{\text {śr. }}$ & 0.20 & 0.20 & 0.28 & 0.23 \\
\hline ALA & ns & ns & ns & ns \\
\hline UA & 0.23 & & ns & ns \\
\hline $\mathrm{XO}$ & 0.21 & ns & & 0.29 \\
\hline
\end{tabular}

$\mathrm{p}<0.05$.

ns - non-significant / nieistotne statystycznie.

Other abbreviations as in Table 1 / Inne objaśnienia jak w tabeli 1.

Purine metabolism in humans leads to the formation of UA that is present intracellularly and in all body fluids and excreted in the urine. Uric acid has been proposed to be one of the most important low-molecular-mass antioxidants in the human biological fluids. It is believed that UA does not only act as a radical scavenger, but also chelates metal ions and converts them to poorly reactive forms unable to catalyse free-radical reactions. On the other hand, some studies indicate that UA has proinflammatory properties (16) and can cause endothelial dysfunction through the stimulation of vascular smooth muscle proliferation. Besides, the elevated levels of UA are known to inhibit the release of nitric oxide within the vasculature of kidneys resulting in reduced renal blood flow and glomerular filtration rate (5).

The association between lead-exposure and the elevation of UA has been investigated in various studies in both occupationally exposed and general population. It has been reported that much lower, than it was previously thought, lead doses cause the increase in serum uric acid level (5). However, in the present study, significantly elevated UA level was observed only in the high tertile. Slightly but significantly elevated levels of creatinine in the medium and high tertile were simultaneously observed. Despite not so strong correlation between the levels of UA and creatinine $(r=0.23)$, the obtained results indicate that UA elevation in the examined population may be due not only to XO induction but also to lead-induced nephropathy. Other studies rather support our research. Alasia et al. (5) reported elevated UA and creatinine levels in lead-exposed workers $(\mathrm{PbB}=50.4 \pm 24.6 \mu \mathrm{g} / \mathrm{dl})$. In this study, UA level correlated positively with serum creatinine level $(r=0.134)$ and negatively with creatinine clearance $(r=-0.151)$. After the adjustment for age, weight and height, Ehrlih et al. (17) also found positive exposure response relations between lead-exposure indices and serum creatinine and UA concentrations in exposed workers $(\mathrm{PbB}=53.5 \mu \mathrm{g} / \mathrm{dl})$. Consistently, Khan et al. (18) reported elevated UA level and positive correlations between $\mathrm{PbB}$ and serum creatinine $(\mathrm{r}=0.51)$ and UA $(\mathrm{r}=0.29)$ levels in lead-exposed workers $(\mathrm{PbB}=29.1 \mu \mathrm{g} / \mathrm{dl})$. On the other hand, Omae et al. (19) and Roels et al. (20) investigated workers exposed to lead and concluded that exposure up to $70 \mu \mathrm{g} / \mathrm{dl}$ of $\mathrm{PbB}$ may not cause adverse effects on renal function. However, when examining aboriginals and non-aboriginals living in Taiwan, Lai et al. (21) reported that people with $\mathrm{PbB}$ exceeding even $7.5 \mu \mathrm{g} / \mathrm{dl}$ are at a higher risk of renal dysfunction and hyperuricemia. Despite the discrepancies between the above-mentioned results, it is possible to state that there is a dose-effect relationship between blood lead and the UA level.

Lipids are the principal targets of oxidative stress because they easily undergo oxidation. Malondialdehyde is the most studied product of polyunsaturated fatty acid peroxidation and it is able to impair several physiological mechanisms of human body through its reactivity with DNA and proteins (22). The elevated concentration of erythrocyte MDA observed in the present study confirms the potency of lead to induce oxidative stress and may be partially caused by increased XO activity. A positive correlation between the MDA level and XO activity $(r=0.29)$, observed in the present study, supports this hypothesis. Positive correlations between MDA level and indices of lead-exposure were shown as well. Consistently, elevated MDA levels were reported in many studies conducted on both lead-exposed animals and humans. Our previous reports also showed increased MDA levels in workers exposed to lead (23-25).

\section{CONCLUSIONS}

Occupational exposure to lead induces activity of XO. This induction may be due to the increased conversion of XOR to XO. Elevated XO activity may have contributed to the observed simultaneously increased oxidative stress, measured as MDA level, and the increased level of UA. 


\section{REFERENCES}

1. Krishnan E, Lingala B, Bhalla V. Low-level lead exposure and the prevalence of gout: an observational study. Ann Int Med 2012;157(4):233-41.

2. Wang J, Yang Z, Lin L, Zhao Z, Liu Z, Liu X. Protective effect of naringenin against lead-induced oxidative stress in rats. Biol Trace Elem Res 2012;146(3):354-9.

3. Kasperczyk A, Machnik G, Dobrakowski M, Sypniewski D, Birkner E, Kasperczyk S. Gene expression and activity of antioxidant enzymes in the blood cells of workers who were occupationally exposed to lead. Toxicology 2012;301(1-3):79-84.

4. Kasperczyk A, Prokopowicz A, Dobrakowski M, Pawlas N, Kasperczyk S. The effect of occupational lead exposure on blood levels of zinc, iron, copper, selenium and related proteins. Biol Trace Elem Res 2012;150(1-3):49-55.

5. Alasia DD, Emem-Chioma PC, Wokoma FS. Association of lead exposure, serum uric acid and parameters of renal function in Nigerian lead-exposed workers. Int J Occup Environ Med 2010;1(4):182-90.

6. Harzand A, Tamariz L, Hare JM. Uric acid, heart failure survival, and the impact of xanthine oxidase inhibition. Conqest Heart Fail 2012;18(3):179-82.

7. Ariza ME, Bijur GN, Williams MV. Lead and mercury mutagenesis: role of $\mathrm{H} 2 \mathrm{O} 2$, superoxide dismutase, and xanthine oxidase. Environ Mol Mutagen 1998;31(4): $352-61$.

8. Grabecki J, Haduch T, Urbanowicz H. Simple determination methods of delta-aminolevulinic acid in urine. Int Arch Arbeitsmed 1967;23(3):226-40 [in German].

9. Majkić-Singh N, Bogavac L, Kalimanovska V, Jelić Z, Spasić S. Spectrophotometric assay of xanthine oxidase with 2,2'-azino-di(3-ethylbenzthiazoline-6-sulphonate) (ABTS) as chromogen. Clin Chim Acta 1987;162(1): $29-36$.

10. Ohkawa H, Ohishi N, Yagi K. Assay for lipid peroxides in animal tissues by thiobarbituric acid reaction. Anal Biochem 1979;95(2):351-8.

11. Bajaj K, Burudkar S, Shah P, Keche A, Ghosh U, Tannu P, et al. Lead optimization of isocytosine-derived xanthine oxidase inhibitors. Bioorg Med Chem Lett 2013;23(3):834-8. DOI: 10.1016/j.bmcl.2012.11.057.

12. George J, Struthers AD. Role of urate, xanthine oxidase and the effects of allopurinol in vascular oxidative stress. Vasc Health Risk Manag 2009;5(1):265-72.

13. Nishino T, Okamoto K, Eger BT, Pai EF, Nishino T. Mammalian xanthine oxidoreductase - mechanism of transi- tion from xanthine dehydrogenase to xanthine oxidase. FEBS J 2008;275(13):3278-89.

14. Kilikdar D, Mukherjee D, Mitra E, Ghosh AK, Basu A, Chandra AM, et al. Protective effect of aqueous garlic extract against lead-induced hepatic injury in rats. Indian J Exp Biol 2011;49(7):498-510.

15. Prasanthi RP, Devi CB, Basha DC, Reddy NS, Reddy GR. Calcium and zinc supplementation protects lead $(\mathrm{Pb})$-induced perturbations in antioxidant enzymes and lipid peroxidation in developing mouse brain. Int J Dev Neurosci. 2010;28(2):161-7.

16. Glantzounis GK, Tsimoyiannis EC, Kappas AM, Galaris DA. Uric acid and oxidative stress. Curr Pharm Des 2005;11(32):4145-51.

17. Ehrlich R, Robins T, Jordaan E, Miller S, Mbuli S, Selby $\mathrm{P}$, et al. Lead absorption and renal dysfunction in a South African battery factory. Occup Environ Med 1998;55(7):453-60.

18. Khan DA, Qayyum S, Saleem S, Khan FA. Lead-induced oxidative stress adversely affects health of the occupational workers. Toxicol Ind Health 2008;24(9):611-8.

19. Omae K, Sakurai H, Higashi T, Muto T, Ichikawa M, Sasaki N. No adverse effects of lead on renal function in lead-exposed workers. Ind Health 1990;28(2):77-83.

20. Roels H, Lauwerys R, Konings J, Buchet JP, Bernard A, Green S, et al. Renal function and hyperfiltration capacity in lead smelter workers with high bone lead. Occup Environ Med 1994;51(8):505-12.

21. Lai LH, Chou SY, Wu FY, Chen JJ, Kuo HW. Renal dysfunction and hyperuricemia with low blood lead levels and ethnicity in community-based study. Sci Total Environ 2008;401(1-3):39-43.

22. Del Rio D, Stewart AJ, Pellegrini N. A review of recent studies on malondialdehyde as toxic molecule and biological marker of oxidative stress. Nutr Metab Cardiovasc Dis 2005;15(4):316-28.

23. Kasperczyk S, Birkner E, Kasperczyk A, Kasperczyk J. Lipids, lipid peroxidation and 7-ketocholesterol in workers exposed to lead. Hum Exp Toxicol 2005;24(6):287-95.

24. Kasperczyk S, Birkner E, Kasperczyk A, Zalejska-Fiolka J. Activity of superoxide dismutase and catalase in people protractedly exposed to lead compounds. Ann Agric Environ Med 2004;11(2):291-6.

25. Kasperczyk S, Kasperczyk A, Ostalowska A, Dziwisz M, Birkner E. Activity of glutathione peroxidase, glutathione reductase, and lipid peroxidation in erythrocytes in workers exposed to lead. Biol Trace Elem Res 2004;102(1-3): $61-72$.

This work is licensed under a Creative Commons Attribution-NonCommercial 3.0 Poland License / Ten utwór jest dostępny na licencji Creative Commons Uznanie autorstwa - Użycie niekomercyjne 3.0 Polska - http://creativecommons.org/licenses/by-nc/3.0/pl/. 